\title{
The harvest of freshwater turtles (Chelidae) from Papua, Indonesia, for the international pet trade
}

\author{
Jessica Ann Lyons, Daniel James Deans Natusch and Chris R. Shepherd
}

\begin{abstract}
The international trade in wildlife is currently one of the greatest threats to biodiversity. One group, the turtles, has experienced far-reaching population declines and extinctions because the majority of animals are sourced from the wild. The island of New Guinea has the highest diversity of freshwater turtles (Chelidae) in the Australasian region and large numbers are harvested from the Indonesian province of Papua to supply the international pet trade. A total of 264 of these turtles representing six species were recorded between December 2010 and March 2011 while gathering information about wildlife trade in the Indonesian province of Papua. Most were juveniles, although a substantial number of large adults were also harvested. None of the species recorded are CITES-listed. Despite one species not being allocated an annual harvest quota, it was observed being traded. Illegal and unregulated trade coupled with a lack of basic ecological data for these species can have a severe impact on wild populations. We present recommendations for law enforcement and conservation of these species.
\end{abstract}

Keywords Chelidae, Chelodina, conservation status, Elseya, Emydura, freshwater turtles, New Guinea, wildlife trade

\section{Introduction}

T ild species are traded in large numbers and the international trade is believed to be worth billions of dollars annually (Roe, 2008; Smith et al., 2009). Demand is diverse, and includes the markets for food, luxury goods, tourist curios, medicines and live animals for the pet trade (Nijman, 2010). Overexploitation is one of the main threats to species because wild populations are often harvested unsustainably or illegally (Shepherd et al., 2004; Warchol, 2004).

Basic biological and ecological data are lacking for many of the species traded and it is difficult to determine if the

Jessica AnN Lyons (Corresponding author) and Daniel James DeAns NatusCH School of Biological, Earth and Environmental Sciences, University of New South Wales, Sydney, New South Wales, Australia

E-mail jess.lyons87@gmail.com

CHRIS R. SHEPHERD TRAFFIC South-east Asia, Petaling Jaya, Selangor, Malaysia

Received 21 January 2012. Revision requested 9 May 2012.

Accepted 11 June 2012. trade is sustainable. One group of animals heavily exploited for the pet trade are the turtles (Lau et al., 2000; Lee et al., 2005; Cheung \& Dudgeon, 2006; Shepherd, 2007; Shepherd \& Nijman, 2007; Gong et al., 2009; Nijman et al., 2012). Large numbers of turtles are sourced from Asia and collectively their decline has been dubbed the Asian turtle crisis (van Dijk et al., 2000). The decline in wild turtle populations is driven mainly by overexploitation, together with habitat degradation and loss (Thirakhupt \& van Dijk, 1994; Klemens \& Thorbjarnarson, 1995; Das, 1997; Gibbons et al., 2000; van Dijk et al., 2000; Moll \& Moll, 2004; Cheung \& Dudgeon, 2006; Krishnakumar et al., 2009; Horne et al., 2012).

The freshwater turtle family Chelidae is restricted to South America, Australia, Indonesia and New Guinea (Georges \& Thomson, 2010). The island of New Guinea (divided politically into Papua New Guinea and Indonesia) has the highest diversity of chelid turtles in the Australasian region, with at least 13 species currently recognized, 10 of which are endemic (Rhodin \& Genorupa, 2000; Allison, 2006). Despite a number of recent studies on the ecology of these turtles, further research into their trade has been prompted by large harvests by indigenous peoples for food, carapaces (fashioned into curios such as masks) and for the pet trade (Rhodin \& Genorupa, 2000; Samedi \& Iskandar, 2000; Georges et al., 2008; Eisemberg et al., 2011).

Currently, none of the known 13 species of New Guinea chelid turtle are listed in the appendices of CITES (CITES, 2011), meaning that their international trade is not monitored or regulated. In Indonesia chelid turtles are traded under a quota system that is set annually by a meeting of various stakeholders, which includes the Indonesian CITES Management Authority, the Directorate General of Forest Protection and Nature Conservation (PHKA) and CITES Scientific Authority, the Indonesian Institute of Sciences (LIPI), relevant NGOs, and licensed wildlife traders. Harvest and export quotas are set for all non-protected species, including CITES and non-CITES listed species. Little work on wildlife trade has been conducted in Indonesian New Guinea (but see Rhodin \& Genorupa, 2000; Georges et al., 2006), which incorporates the provinces of Papua and West Papua. It is suspected that significant trade in chelid turtles is occurring to supply international pet markets (Samedi \& Iskandar, 2000) and unsustainable trade may already be a significant threat for Indonesian freshwater turtle populations (Rhodin \& Genorupa, 2000; Shepherd \& Nijman, 
2007). The present study provides data on the trade of six chelid turtle species from Indonesian New Guinea.

\section{Methods}

We (JAL, DJDN) visited the town of Merauke in the Indonesian province of Papua between December 2010 and March 2011 (Fig. 1). Data on the chelid turtle trade were gathered opportunistically while conducting other work on wildlife trade in the region (Natusch \& Lyons, 2012a). We identified wildlife traders through anonymous informants and using snowball sampling, which used recommendations from wildlife traders to establish contact with other traders (Bryman, 2004). We gathered data continuously during this period for one wildlife trader and we visited another once in December 2010 and once in March 2011. Both traders mentioned there was an additional dealer who apparently traded solely in turtles; however, we were unable to contact him.

We identified turtles using an identification key (Georges et al., 2006) and classified them in accordance with recent taxonomic revisions (Georges \& Thomson, 2010). We recorded maximum carapace length (MCL), measured in a straight line to the nearest $0.5 \mathrm{~cm}$ with a steel measuring ruler, body mass, to the nearest $1 \boldsymbol{g}$ using Pesola spring scales, and sex, determined using external dimorphic characteristics, particularly tail length, which is much greater in mature males (Georges et al., 2006). Sex could not be determined for small or obviously immature individuals. We grouped turtles into three arbitrary size categories according to MCL: small $(<12 \mathrm{~cm})$, medium $(12-20 \mathrm{~cm})$ and large $(>20 \mathrm{~cm})$.

\section{Results}

We recorded 264 chelid turtles, of six species, between December 2010 and March 2011 (Table 1). Most had been collected from rivers and swamps by local people in the villages of Kumbe and Salor, near Merauke, but turtles were also harvested from more remote areas such as Okaba and Muting (Fig. 1). Both villagers and wildlife traders claimed that turtles were also collected from the nearby Wasur National Park.

The number, MCL and mean body mass of the six species of chelid turtle encountered is listed in Table 1. The New Guinea painted turtle Emydura subglobosa was most frequently recorded, followed by the northern snake-necked turtle Chelodina (Macrochelodina) rugosa (Table 1). Wildlife traders stated that juveniles or subadults are preferred to adults because their smaller size and weight reduced shipping costs; size class distributions of each chelid turtle traded in Merauke are shown in Fig. 2. A two-way analysis of covariance with sex and species as factors, $\log _{10} \mathrm{MCL}$ as the

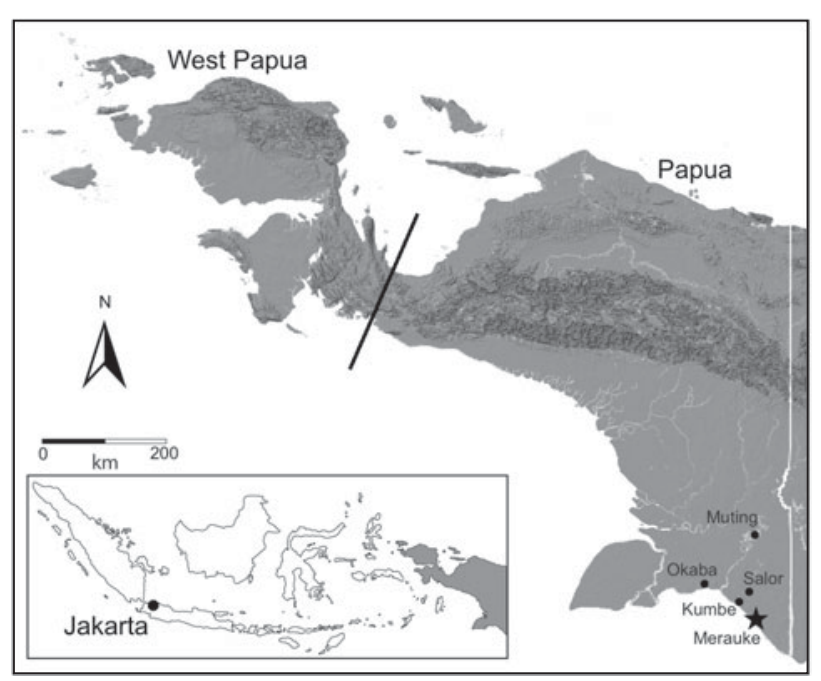

FIG. 1 The town of Merauke and the surrounding villages of Kumbe, Muting, Salor and Okaba in the Indonesian province of Papua. The black line approximates the border between the provinces of West Papua and Papua. The inset map indicates the location of the Indonesian capital, Jakarta, in relation to the island of New Guinea (shaded).

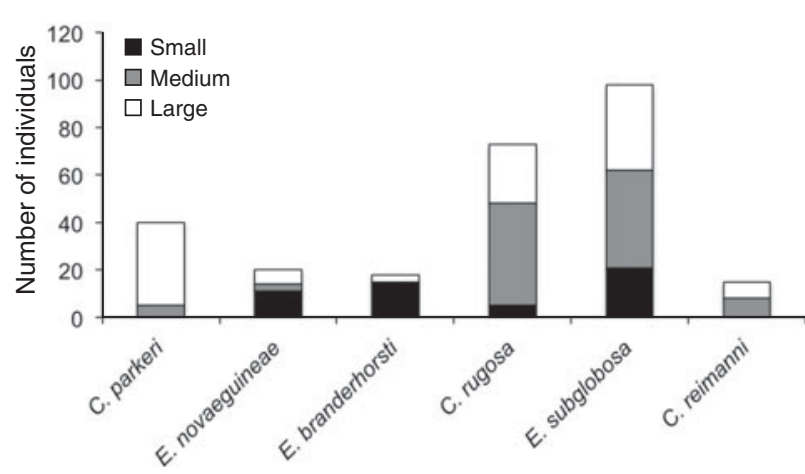

FIG. 2 Size class distributions of the six species of chelid turtle (Table 1) traded in Merauke.

covariate and $\log _{10}$ body mass as the dependent variable revealed no significant difference in relative body mass between species $\left(F_{(3,127)}=0.73, \mathrm{P}=0.54\right)$, or between males and females $\left(F_{(1,127)}=0, P=0.95\right)$. Contingency table analysis revealed no bias towards the sex of the turtles collected $(\mathrm{P}>0.05)$, except for Reimann's long-necked turtle Chelodina reimanni, but this could be because of the small number recorded (Table 1).

Over the 4-month study period turtles were sold to wildlife traders on a continuous basis, with peaks occurring when middlemen delivered shipments of turtles from surrounding villages (Fig. 3). Most traders kept turtles for an extended period of time (1-2 months) until a substantial number of individuals had been accumulated (represented by the peaks at the beginning and end of Fig. 3), before sending them by plane to breeding farms and exporters in Jakarta. We observed $>30$ turtles that had died while awaiting shipment. 
TABle 1 The six species of chelid turtle found to be traded in Papua Province, Indonesia, with number located (N), mean maximum carapace length (MCL) and mean body mass, by sex.

\begin{tabular}{|c|c|c|c|c|c|}
\hline Species & Sex & $\mathrm{N}$ & $\mathrm{MCL} \pm \mathrm{SD}(\mathrm{cm})$ & Range & $\begin{array}{l}\text { Mean body } \\
\text { mass } \pm S D(g)\end{array}$ \\
\hline \multirow[t]{2}{*}{ Parker's snake-necked turtle Chelodina parkeri } & Female & 20 & $22.8 \pm 1.2$ & $20.0-25.0$ & $1,307.9 \pm 242.6$ \\
\hline & Male & 20 & $20.5 \pm 0.9$ & $19.0-22.5$ & $923.2 \pm 117.2$ \\
\hline \multirow[t]{2}{*}{ Reimann's long-necked turtle Chelodina reimanni } & Female & 13 & $18.0 \pm 3.8$ & $13.2-22.0$ & $652.5 \pm 425.8$ \\
\hline & Male & 2 & $20.7 \pm 0.3$ & $20.4-20.9$ & $961.0 \pm 18.3$ \\
\hline \multirow{2}{*}{$\begin{array}{l}\text { Northern snake-necked turtle } \\
\text { Chelodina (Macrochelodina) rugosa }\end{array}$} & Female & 35 & $17.0 \pm 4.4$ & $10.8-28.7$ & $702.0 \pm 754.0$ \\
\hline & Male & 38 & $19.8 \pm 4.2$ & $10.9-26.8$ & $1,158.2 \pm 643.0$ \\
\hline \multirow[t]{3}{*}{ New Guinea snapping turtle Elseya branderhorst $i$} & Female & 5 & $18.5 \pm 7.3$ & $10.5-25.0$ & $959.0 \pm 976.7$ \\
\hline & Male & 2 & $28.1 \pm 1.0$ & $28.0-28.2$ & $2,463.0 \pm 126.1$ \\
\hline & Unknown & 11 & $5.0 \pm 2.3$ & $4.0-11.9$ & $29.9 \pm 57.6$ \\
\hline \multirow[t]{3}{*}{ New Guinea spotted turtle Elseya novaeguineae } & Female & 6 & $22.1 \pm 1.0$ & $20.0-23.0$ & $1,334.0 \pm 279.1$ \\
\hline & Male & 7 & $20.8 \pm 1.5$ & $18.7-22.3$ & $997.3 \pm 229.0$ \\
\hline & Unknown & 7 & $11.2 \pm 2.5$ & $8.7-15.5$ & $169.6 \pm 146.0$ \\
\hline \multirow[t]{3}{*}{ New Guinea painted turtle Emydura subglobosa } & Female & 47 & $20.8 \pm 1.6$ & $17.6-25.5$ & $1,013.9 \pm 265.6$ \\
\hline & Male & 36 & $16.9 \pm 2.2$ & $10.1-20.0$ & $518.3 \pm 160.4$ \\
\hline & Unknown & 15 & $4.1 \pm 2.5$ & $2.7-11.0$ & $16.4 \pm 41.7$ \\
\hline
\end{tabular}

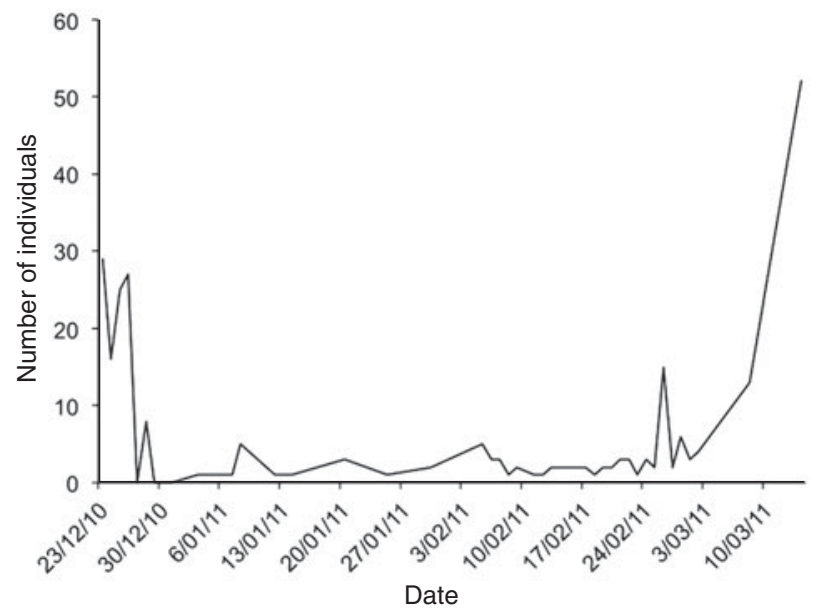

FIG. 3 Timeline of the total number of six species of chelid turtle (Table 1) traded between December 2010 and March 2011.

Of the six chelid species recorded, none are listed in the CITES Appendices. Two species are categorized on the IUCN Red List as Vulnerable, two as Least Concern, one as Lower Risk and one has not been assessed (Table 2). The pig-nosed turtle Carettochelys insculpta, which is highly sought-after for the pet trade, was not being traded despite 60 wild individuals being offered for sale by a local fisherman. Because they are protected, the trader refused these turtles, possibly because illegal shipments of $C$. insculpta are regularly seized by officials (Anon, 2010; So, 2011; TRAFFIC, 2012). New Guinea snapping turtles Elseya branderhorsti were, however, found to be traded despite not having an allotted harvest quota (which makes their collection and trade illegal). New Guinea spotted turtles are fully protected in Indonesia but this species is allocated a harvest quota
TABLE 2 IUCN Red List category (IUCN, 2012) and criteria (IUCN, 2001), and 2011 annual harvest quotas for the six species of chelid turtle found traded (Table 1).

\begin{tabular}{|c|c|c|}
\hline Species & $\begin{array}{l}\text { IUCN category } \\
\text { (criteria) }\end{array}$ & $\begin{array}{l}\text { Annual harvest } \\
\text { quota }(2011)^{1}\end{array}$ \\
\hline $\begin{array}{l}\text { Parker's snake-necked } \\
\text { turtle }\end{array}$ & Vulnerable (D2) & 150 \\
\hline $\begin{array}{l}\text { Reimann's long-necked } \\
\text { turtle }\end{array}$ & $\begin{array}{l}\text { Lower Risk: near } \\
\text { threatened }\end{array}$ & 100 \\
\hline $\begin{array}{l}\text { Northern snake-necked } \\
\text { turtle }^{2}\end{array}$ & Not assessed & 1,000 \\
\hline $\begin{array}{l}\text { New Guinea snapping } \\
\text { turtle }\end{array}$ & $\begin{array}{l}\text { Vulnerable } \\
(\mathrm{B} 1+2 \mathrm{e})\end{array}$ & No quota \\
\hline New Guinea spotted turtle ${ }^{3}$ & Least Concern & No quota \\
\hline New Guinea painted turtle & Least Concern & 500 \\
\hline
\end{tabular}

${ }^{1}$ All species are exported for 'pets' as specified in the Indonesian quota system, except the New Guinea snapping turtle, which it is illegal to harvest or export

${ }^{2}$ Referred to by the synonym Chelodina siebenrocki within the Indonesian quota system

${ }^{3}$ This species is fully protected in Indonesia, yet is traded via the quota system under the older synonym Elseya schultzei

under an older synonym, E. schultzei, and is still collected for trade. The remaining four species of turtle observed in trade have quotas that are divided equally between the provinces of West Papua and Papua, even though none of them are known to occur in West Papua (Georges \& Thomson, 2010; Natusch \& Lyons, 2012b). In addition, Parker's turtle Chelodina parkeri is known only from the Fly River and its tributaries in Papua New Guinea and it is possible that the individuals we observed were brought across the Indonesian-Papua New Guinea border to be sold (Rhodin \& Genorupa, 2000). 


\section{Discussion}

This study shows that large numbers of chelid turtles are being exported from Indonesian New Guinea for the international pet trade. Such trading is of conservation concern as little is known about the distribution or population status of these species. Moreover, it is difficult to assess the sustainability of this trade because none are CITES-listed and export and domestic trade levels are unknown. Population declines have already occurred for another species of chelid turtle, the Roti Island snake-necked turtle Chelodina mccordi, which has been overexploited for the pet trade in Indonesia (Shepherd \& Ibarrondo, 2005; Rhodin et al., 2008).

Many overexploited turtle species are vulnerable to extinction because of their slow maturation rates and low fecundity, making them unable to reproduce quickly enough to sustain trade sourced from wild populations (Congdon et al., 1993). This also makes commercial farming unattractive as turtles are costly to breed, house and feed for extended periods. The result is that wild-caught animals are frequently laundered through farms under the guise of being captive-bred (Nijman \& Shepherd, 2009; Vinke \& Vinke, 2010; Lyons \& Natusch, 2011).

Indonesia has adequate legislation to control the harvest and trade of wildlife from point of capture to export However, harvest and export quotas are often arbitrarily set and sustainability estimates are not based on scientifically sound research (Soehartono \& Mardiastuti, 2002; Schoppe, 2009). Furthermore, harvest quotas are often inadequately monitored and enforced because of a lack of human resources and funding (Lee et al., 2005), undermining efforts to ensure that species are not overexploited (Shepherd, 2007; Shepherd \& Nijman, 2007). Existing laws and regulations concerning trade in freshwater turtles need to be rigorously enforced in Indonesia and punishments for violation should be enforced to the maximum extent of the appropriate laws (Horne et al., 2012).

Clearly, there is an urgent need to assess both the levels of exploitation of chelid turtle species in Indonesia and to determine a sustainable level of harvest for each. This should include exploration of appropriate proxies for CITES non-detriment findings. However, the general lack of knowledge of the distribution, ecology and biology of these turtle species makes it difficult to identify practices for sustainable exploitation. For example, Indonesia's current harvest quotas for chelid turtles apply to the provinces of both West Papua and Papua (Table 2). With the exception of Elseya novaeguineae (and possibly E. subglobosa), however, these turtle species do not occur in West Papua province (Natusch \& Lyons, 2012b). Further studies of the trade in chelid turtles in Papua are needed, together with enforcement of domestic and international laws and conventions, to ensure population of these species do not decline. We also suggest that Indonesian authorities recognize recent taxonomic changes, to avoid confusion relating to trade using older synonyms.

The information presented here supports the recommendations of van Djik et al. (2000) and Horne et al. (2012) for inclusion of New Guinea's chelid turtle species in the Appendices of CITES. This is an important first step, and would enable the international community to assist Indonesian authorities in monitoring exports and enforcing harvest and export restrictions to ensure that chelid populations are being sustainably harvested.

\section{Acknowledgements}

We thank the Indonesian traders who allowed us to examine turtles in their care, and two anonymous reviewers for their helpful comments. This work was conducted in accordance with the University of New South Wales Animal Ethics protocols.

\section{References}

Allison, A. (2006) Reptiles and Amphibians of the Trans-Fly region, New Guinea. Report submitted to WWF South Pacific Programme Pacific Biological Survey, Honolulu, Hawaii, USA.

ANON (2010) Papua police foil attempt to smuggle out pig-nosed turtles. Antara News, 29 December.

Bryman, A. (2004) Social Research Methods, 2nd edition. Oxford University Press, New York, USA.

Cheung, S.M. \& Dudgeon, D. (2006) Quantifying the Asian turtle crisis: market surveys in southern China, 2000-2003. Aquatic Conservation Marine and Freshwater Ecosystems, 16, 751-770.

CITES (2011) What is CITES? Http://www.cites.org/eng/disc/what. php [accessed June 2011].

Congdon, J.D., Durnham, A.D. \& Van Loben Sels, R.C. (1993) Delayed sexual maturity and demographics of Blandings turtles (Emydoidea blandingii): implications for conservation and management of long-lived organisms. Conservation Biology, $7,826-833$

DAs, I. (1997) Conservation problems of tropical Asia's most threatened turtles. In Proceedings: Conservation, Restoration and Turtles: An International Conference (ed. J. Abbema), pp. 295-300. New York Turtle and Tortoise Society and Wildlife Conservation Society Turtle Recovery Program, New York, USA.

Eisemberg, C.C., Rose, M., Yaru, B. \& Georges, A. (2011) Demonstrating decline of an iconic species under sustained indigenous harvest-the pig-nosed turtle (Carettochelys insculpta) in Papua New Guinea. Biological Conservation, 144, 2282-2288.

Georges, A., Doody, J.S., Eisemberg, C., Alacs, E.A. \& Rose, M. (2008) Carettochelys insculpta Ramsay 1886: pig-nosed turtle, fly river turtle. Chelonian Research Monographs, 5, 9.1-9.17.

Georges, A., Guarino, F. \& Bito, B. (2006) Freshwater turtles of the Trans-Fly region of Papua New Guinea-Notes on diversity, distribution, reproduction, harvest and trade. Wildlife Research, 33, 373-384.

Georges, A. \& Thomson, S. (2010) Diversity of Australasian freshwater turtles, with an annotated synonymy and keys to species. Zootaxa, 2496, 1-37. 
Gibbons, J.W., Scott, D.E., Ryan, T.J., Buhlmann, K.A., Tuberville, T.D. \& MetTs, B.S. (2000) The global decline of reptiles, déjà vu amphibians. BioScience, 50, 653-666.

GonG, S., Chow, A., FonG, J.J. \& SHI, H. (2009) The chelonian trade in the largest pet market in China: scale, scope and impact on turtle conservation. Oryx, 43, 213-216.

Horne, B.D., Poole, C.M. \& Walde, A.D. (eds) (2012) Conservation of Asian tortoises and freshwater turtles: setting priorities for the next ten years. Recommendations and Conclusions from the Workshop in Singapore, 21-24 February 2011. Wildlife Conservation Society/Turtle Survival Alliance, Singapore.

IUCN (2001) IUCN Red List Categories and Criteria v. 3.1. IUCN, Gland, Switzerland, and Cambridge, UK. Http://www.iucnredlist. org/technical-documents/categories-and-criteria [accessed 22 November 2012].

IUCN (2012) The IUCN Red List of Threatened Species v. 2012.2. Http://www.iucnredlist.org [accessed 22 November 2012].

Klemens, M.W. \& Thorbjarnarson, J.B. (1995) Reptiles as a food resource. Biodiversity and Conservation, 4, 281-298.

Krishnakumar, K., Raghavan, R. \& Pereira, B. (2009) Protected on paper, hunted in wetlands: exploitation and trade of freshwater turtles (Melanochelys trijuga coronata and Lissemys punctata punctata) in Punnamada, Kerala, India. Tropical Conservation Science, 2, 363-373.

Lau, M., Chan, B., Crow, P. \& Ades, G. (2000) Trade and conservation of turtles and tortoises in the Hong Kong Special Administrative Region, People's Republic of China. Chelonian Research Foundation, 2, 39-44.

Lee, R.J., Gorog, A.J., Dwiyahreni, A., Siwu, S., Riley, J., Alexander, H. et al. (2005) Wildlife trade and implications for law enforcement in Indonesia: a case study from north Sulawesi. Biological Conservation, 123, 477-488.

Lyons, J.A. \& Natusch, D.J.D. (2011) Wildlife laundering through breeding farms: illegal harvest, population declines and a means of regulating the trade of green pythons (Morelia viridis) from Indonesia. Biological Conservation, 144, 3073-3081.

Moll, D. \& Moll, E.O. (2004) The Ecology, Exploitation, and Conservation of River Turtles. Oxford University Press, Oxford, UK.

Natusch, D.J.D. \& Lyons, J.A. (2012a) Distribution, ecological attributes and trade of the New Guinea carpet python (Morelia spilota) in Indonesia. Australian Journal of Zoology, 59, 236-241.

NAtusch, D.J.D. \& Lyons, J.A. (2012b) Exploited for pets: harvest and trade of amphibians and reptiles from Indonesian New Guinea. Biodiversity and Conservation, 21, 2899-2911.

Nijman, V. (2010) An overview of international wildlife trade from South-east Asia. Biodiversity and Conservation, 19, 1101-1114.

Nijman, V. \& Shepherd, C.R. (2009) Wildlife Trade from the ASEAN to the EU: Issues with the Trade in Captive-Bred Reptiles from Indonesia. TRAFFIC Europe Report for the European Commission, Brussels, Belgium.

Nijman, V., Shepherd, C.R., Mumpuni \& Sanders, K.L. (2012) Over-exploitation and illegal trade of reptiles in Indonesia. Herpetological Journal, 22, 83-89.

Rhodin, A.G.J. \& Genorupa, V.R. (2000) Conservation status of freshwater turtles in Papua New Guinea. Chelonian Research Monographs, 2, 129-136.

Rhodin, A.G.J., Ibarrondo, B.R. \& Kuchling, G. (2008) Chelodina mccordi Rhodin 1994-Roti Island snake-necked turtle, McCord's snake-necked turtle, kura-kura rote. Chelonian Conservation and Biology, 5, 008.1-008.8.

Roe, D. (2008) Trading Nature. A report, with Case Studies, on the Contribution of Wildlife Trade Management to Sustainable Livelihoods and the Millennium Development Goals. TRAFFIC International and WWF International, Gland Switzerland.

Samedi, M.L. \& Iskandar, D.T. (2000) Freshwater side-necked turtle and tortoise conservation and utilization in Indonesia. Chelonian Research Monographs, 2, 106-111.

Schoppe, S. (2009) Status, Trade Dynamics and Management of the South-east Asian Box Turtle in Indonesia. TRAFFIC South-east Asia, Petaling Jaya, Malaysia.

Shepherd, C.R. (2007) Trade in the black-and-white laughing thrush Garrulax bicolor and white-crested laughing thrush G. leucolophus in Indonesia. Birding ASIA, 8, 49-52.

Shepherd, C.R. \& Ibarrondo, B. (2005) The Trade of the Roti Island Snake-necked Turtle Chelodina mccordi. TRAFFIC South-east Asia, Petaling Jaya, Malaysia.

Shepherd, C.R. \& Nijman, V. (2007) An Overview of the Regulation of the Freshwater Side-necked Turtle and Tortoise Pet Trade in Jakarta, Indonesia. TRAFFIC South-east Asia, Petaling Jaya, Malaysia.

Shepherd, C.R., Sukumaran, J. \& Wich, S.A. (2004) Open Season: An Analysis of the Pet Trade in Medan, Sumatra 1997-2001.

TRAFFIC South-east Asia, Petaling Jaya, Malaysia.

Smith, K.F., Behrens, M., Schloegel, L.M., Marano, N., Burgiel, S. \& Daszak, P. (2009) Reducing the risks of the wildlife trade. Science, 324, 594-595.

So, A. (2011) Smuggled Pig-nosed Turtles Ready to Go Home. The Standard Newspapers Publishing, Hong Kong, 4 October.

Soehartono, T. \& Mardiastuti, A. (2002) CITES Implementation in Indonesia. Nagao Natural Environment Foundation, Jakarta, Indonesia.

Thirakhupt, K. \& Van Dijk, P.P. (1994) Species diversity and conservation of turtles in western Thailand. Natural History Bulletin of the SIAM Society, 42, 207-259.

TRAFFIC (2012) Almost 1,500 turtles 'crammed like sardines' into suitcases. Http://www.traffic.org/home/2012/3/2/almost-1500turtles-crammed-like-sardines-into-suitcases.html [accessed March 2012].

Van Dijk, P.P., Stuart, B.L. \& Rhodin, A.G.J. (2000) Asian Turtle Trade: proceedings of a workshop on conservation and trade of freshwater side-necked turtles and tortoises in Asia. Chelonian Research Monographs, 2, 1-164.

Vinke, T. \& Vinke, S. (2010) Do breeding facilities for chelonians threaten their stability in the wild? Schildkröten im Fokus Online Bergheim, 1, 1-18.

WARCHOL, G.L. (2004) The transnational illegal wildlife trade. Criminal Justice Studies, 17, 57-73.

\section{Biographical sketches}

Jessica Ann Lyons is studying the status, conservation and trade of reptiles in Indonesia. Daniel James Deans Natusch currently works on the evolutionary biology, ecology, conservation and sustainable use of reptiles in Australia, Melanesia and South-east Asia. Chris SHePherd has an interest in wildlife trade issues and specifically in the exploitation of Asian turtles. 